\title{
On Pragmatic Idiosyncrasies of Qur'anic Idiomatic Phrasal Verbs
}

\author{
Dr. Ali Yunis Aldahesh \\ The University of Sydney \\ Sydney \\ Australia
}

\begin{abstract}
This article concerns itself with scrutinizing the phenomenon of Qur'anic Idiomatic Phrasal Verbs (henceforth $Q I P V s)$ by attending to its pragmatic properties. The main purpose of this article is to explore the ways by which these idiomatic expressions function within the texture of the Qur'an in an attempt to provide new insights for better understanding of the Qur'anic discourse. Taking relevant pragmatics theories (speech acts, cooperative principle, politeness principle, and irony principle) as a theoretical framework, this study attempts to sketch a precise pragmatic picture of QIPVs. By using qualitative methodology, the article demonstrates that both direct and indirect speech acts are performed by employing the QIPVs. The article also demonstrates that the QIPVs are utilised to flout a number of the maxims of conversation in order to communicate various conversational implicatures. It is the author's hope that this article will be of benefit for both teachers and learners of Qur'anic Arabic and also, by extension, for the Qur'an commentators and translators into other languages. No claim is made here for comprehensiveness.
\end{abstract}

Keywords: Qur'anic Idiomatic Phrasal Verbs, Qur'anic Arabic, Qur'anic discourse, speech acts, cooperative principle, politeness principle, irony principle

\section{Introduction}

In the eighteenth century, the phenomenon of collocating proper verbs with prepositions started to draw the attention of English linguists. They identified a bizarre fusing of verbs and prepositions to produce a significance that is completely different from the total sum of their literal significances. Since then, this phenomenon has been the interest of English grammarians, linguists, pedagogues, and lexicographers. It has been named by them idiomatic English phrasal verb (henceforth IEPV) (Aldahesh, 2009). IEPV may be defined as a combination of two or three elements (a verb + a preposition, a verb + an adverb, or a verb + an adverb + a preposition). The key condition of this combination is to behave idiomatically, i.e., to function as a single unit of meaning in that the combination meaning cannot be comprehended from the total sum of the meanings of its individual parts. Examples of IEPVs include: to carry out, to carry on, to turn up, to turn on, to turn off, to get away with, to black out, to take in, to put up with, etc. (Aldahesh, 2009).

English language aside, Arabic language has its own similar, albeit not identical, phenomenon. Arabic does not allow proper verbs to combine with adverbs. Yet, it allows verbs to combine with prepositions. Thus, out of the three above-mentioned EIPV structures Arabic has only one structure that is a verb + a preposition structure. Like English structures, the Arabic structure satisfies the idiomatic city condition, i.e., it functions as a single unit of meaning in a sense that the structure's overall meaning cannot be grasped from the total sum of the meanings of its individual components. Examples of idiomatic Arabic phrasal verbs (henceforth IAPVs) include: 'at $\bar{a}$ 'alä (to destroy, to finish), 'atā min (to come from), 'atā bi- (to bring), nazara 'ilā (to look at), nazara fì (to investigate) etc. (Aldahesh, 2016b).This structure is quite common and frequent in both written and spoken Arabic. Most importantly, it constitutes a major structure in the Qur'anic discourse. Nevertheless, it has not been given a specific label by classical Arabic linguists. This is due to the fact that classical Arabic linguists would not include prepositions when studying Arabic proper verbs. They deal with prepositions separately without paying attentions to their function when collocating with verbs. This has been said, Modern Arabic linguists have paid a due attention to this crucial structure, which is called by them al-dhamā'im (enclosures)(Al-Shamsān, 1986, p. 252 \& p. 747; and Aldahesh, 2016a, pp.13-16). Yet, the treatment of IAPVs by modern Arabic linguists varies from a scholar to another. A number of them have come across IAPVs in passing without accounting for their peculiarities in detail (e.g., Ryding, 2005). 
Others have devoted book chapters and academic articles to deal with IAPVs in more elaborated manner (e.g., Lentzner, 1977; Heliel, 1994; Al-Shamsān, 1987; and Aldahesh, 2016b). A few researchers, however, have attended to IAPVs profoundly and come up with a number of fruitful insights (Dāwood,2002; Al-Shamsān, 1987; and Aldahesh, 2016a). It must be pointed out that the majority of the aforementioned scholars have made no distinction between the idiomatic and non-idiomatic types of Arabic verb-preposition structure. They erroneously took it for granted that all verb-preposition combinations are 'idioms' (Aldahesh, 2016a).

In his two volumes book Al-Qur'an al-Karīm Wa Tafā 'ul al-Ma 'ānī̄: Dirāsa Dilālya li Ta 'lluq Harf al-Jarr bi alFi'il Wa 'Atharahu fì al-Ma'nā fì al-Qur'an al-Karìm, Dāwood (2002) makes a significant contribution totreatment of verb-preposition structure in the Qur'an.He elaborates on all its occurrences throughout the Qur'anic discourse, attends to its syntactic and semantic shades, and provides a number of prolific insights, charts and statistics on its Qur'anic usage. However, similar to the above-mentioned scholars, Dāwood does not distinguish between the idiomatic and non-idiomatic types of the verb-preposition combinations. Such a drawback, in our view, is due to the perspective from which he approaches this issue, i.e., Ta 'lluq Harf al-Jarr bi al-Fi il Wa 'Atharahu fì al-Ma'nā fì al-Qur'an al-Karīm 'the preposition-verb relation and its impact on meanings in the Qur'an'. By dealing with the verb-preposition phenomenon from such a comprehensive perspective, Dāwood considers all these combinations in the Qur'an.He pays no attention to the fact that some combinations are idiomatic and others are non-idiomatic. It is crucial to know, however, that al-ta 'lluq (relation, attachment/dependency) is one of the dynamic factors that contributes to the idiomaticity of the Arabic verbpreposition combinations. Nevertheless, it is not the only factor. al-ta 'lluq, on the other hand, may occur in many Arabic verb-preposition combinations with no effect on their idiomaticity (Aldahesh, 2016a).Furthermore, in his bookAl-Fi'il fi al-Qur'an al-Karìm Ta 'adyatuhu wa Luzümuhu, al-Shamsān (1986) makes another important contribution. Through his treatment of verbs in the Qur'an, al-Shamsān comes up with a number of important views and provides some valuable tables of verbs and the prepositions with which they typically combine. Yet, like the aforesaid researchers, he does not differentiate between the idiomatic and non-idiomatic types of these combinations. His very perspective (i.e., al-ta 'addī wa al-luzūm 'verb transitivity and intransitivity') is the main reason behind the confusion of the two types of these combinations. Despite the fact that the issue of verb transitivity and/or intransitivity forms another significant factor that may contribute to idiomaticity of the Arabic verb-preposition combinations, yet, similar to al-ta 'lluq, it is not the only factor(Aldahesh, 2016a).It should be confirmed that this study focuses on the idiomatic type of Qur'anic verb-preposition structure, which is featured by being a figurative, metaphorical and non-transparent structure. The non-idiomatic type, however,is not covered in this study due to its straightforward meaning, which cause no difficulty to readers, commentators and translators of the Qur'an.

\section{Theoretical Framework}

Looking at the phenomenon of QIPVs from a pragmatic perspective entails us to draw on a number of relevant pragmatics theories. Contrary to semantics, which focuses on the literal, propositional, and linguistically encoded aspect of meaning, pragmatics studies language in use and concentrates on the functional communicative meaning? In determining this aspect of meaning, ittakes into account both linguistic/ textual and extra linguistic/ contextual peculiarities (Aldahesh, 2016b). The main interest of pragmatics isto explore "those relations between language and context that are grammaticalized, or encoded in the structure of a language [i.e.,] the interrelation of language structure and principles of language usage" (Levinson, 1983, p. 9).Pragmatics scrutinizes the means ofproducing meanings by addresser(s) and how those meanings are understood by addressee(s)within a specific situational context (Aldahesh, 2016b). The realm of pragmatic studies has grown and flourished by proposing the speech acts theory. In his book How to do Things with Words,Austin (1962) introduced the speech act theory, which was advanced later by Searle (1969) in his book Speech Acts: An Essay in the Philosophy of Language. Austin (1962) indicates that when people say words they actually do things with them, i.e., to perform speech acts such as: command, promise, request, apology etc. (Aldahesh, 2016b).These acts "we perform when, for example, we make a complaint or a request, apologize or pay someone a compliment" (Hatim 2001, p. 179).There are three correlated dimensions of speech acts classified by Austin (1962), namely: locutionary, illocutionary and prelocutionary. Austin defines the Locutionary act as the act of performing something in the "full normal sense" (p. 94). It is, he elaborates, "roughly equivalent to uttering a certain sentence with a certain sense and reference, which again is roughly equivalent to 'meaning' in the traditional sense" (p. 109). 
In addition, Austin defines the illocutionary acts "[...] performance of an act in saying something as opposed to performance of an act of saying something" (pp. 99-100) [Emphasis in original]. He illustrates this dimension in "informing, ordering, warning, undertaking, [...], i.e. utterances which have a certain (conventional) force" (p. 109). The prelocutionary act, however, is defined by him as "what we bring about or achieve by saying something, such as convincing, persuading, deterring, and even, say, surprising or misleading" (p. 109) [Emphasis in original].These three dimensions, i.e., the locutionary, illocutionary and prelocutionary acts are the concurrent features of any given speech act where the locutionary signifies the utterance itself, the illocutionary signifies the intended communicative meaning behind that utterance, and the perlocutionary signifies the reaction of that utterance on the addressee (Hale 2004, p. 6; Aldahesh, 2016b, p. 44)Scholars refer to these three dimensions of utterance as 'sense', 'force', and 'effect' respectively (Marogy 2010, p. 61; Hatim 2001, p. 179). The concurrent of these dimensions is summarised in what follows: Speakers utter things (utterance act), and in uttering things they often say things (locutionary act), and in saying things they often do things (illocutionary act). And typically, speakers bother with all this because they want to communicate something to a hearer, and even have some effect on the thought and/or action of that hearer (perlocutionary act) (Harnish 2010, P. 6).

Further, Grice (1975)draws on the theory of speech acts to initiate the notion of cooperative principle(henceforth $\mathrm{CP}$ ) and its maxims. Grice (1975) asserts that participants (i.e., addresser and addressee) in any given communicative situation must adhere to a principle and a set of maxims in order to accomplish certain communicative purposes (cf. James 1980, p. 128; Bell 1991, p. 181; Baker 1992, p. 259; Aldahesh, 2016b, p. 45). The cooperative principle that participants are adhered to followis formulated by Grice (1975)as follows: "Make your conversational contribution such as is required, at the stage at which it occurs, by the accepted purpose or direction of the talk exchange in which you are engaged" (p. 45). Grice (1975)classifies this principle into four categories each of which has a number of maxims. The principle categories and their maxims are listed in what follows:

1) Quantity: i) Make your contribution as informative as is required (for the current purposes of the exchange); ii) Do not make your contribution more informative than is required.

2) Quality: i) Do not say that for which you lack adequate evidence; ii) Do not say what you believe to be false. Relation: i) Be relevant.

3) Manner: i) Avoid obscurity of expression; ii) Avoid ambiguity; iii) Be brief (avoid unnecessary prolixity); iv) Be orderly (Aldahesh, 2016b, p. 45).

Interlocutors in everyday conversations quite often flout and infringe these maxims. In so doing, they presume addressees to observe the infringements and draw conclusions. When the addressees observe these infringements they continue to assume that the interlocutors are "making infringements for a good reason. These conclusions are referred to by Grice as conversational implicatures" (James 1980, p. 128) [Emphasis in original].Furthermore, conversational implicatures are divided into two types, namely standard conversational implictures and particularized conversational implictures. The former type of implicatures "are produced by observing the conversational maxims and subsequently perceived through the inferential amplification of what is said to reach out for what is implicated" (Farghal 1995, p. 368).The latter type of implicatuters, however,occur "by flouting one or more of the conversational maxims in order to exploit them for communicative purposes" (Farghal 1995, p. 368).These types are exemplified in the difference between example 1 and example 2 below:

(1) Ali has five acres of land.

(2) Ali has only five acres of land.

The speaker of example 1 "observes the maxim of quantity by implicating in a standard way that Ali has only five acres of land and no more". The speaker of example 2, on the other hand, "flouts the maxim of quantity by saying more than is required, thus giving rise to particularized conversational implicature (i.e., the intention to communicate something such as: 'Ali is unimportant person', 'Ali is a poor person', 'Ali is a lazy person' or all of these collectively)"'(Farghal 1995, p. 368). Having said that, pragmatic analysis of speech acts entails looking at the functions of all utterances from two distinct perspectives, namely: "'stating' and 'doing things', of having a meaning and a force" (Hatim 2001, p. 179). Grice (1975), in this respect, proposes two levels of analysis, namely: the level of what is said and the level of what is implicated. 
Flouting a maxim at the level of what is said by the addresser makes the addressee "entitled to assume that that maxim, or at least the overall Cooperative Principle, is observed at the level of what is implicated" (Grice 1975, p. 52).It is necessary to say that deliberate flouting of a maxim could happen for personal reasons (e.g., when the addresser wishes to mislead the addressee), or for some rhetorical purposes such as: exaggeration, irony, etc. (Marogy 2010, p. 63).Other pragmatic principles relevant to our topic are politeness principle (henceforth PP) and irony principle (henceforth IP) proposed by Leech (1983). As for the politeness principle, there exist a close interaction between Leech's PP and Grice'sCP and its maxims of conversation. The latter is supplemented by the former, which goes hand in hand with it (Farghal, 1995). The PP as explained by Leech (1983) "concerns a relationship between two participants [...] self and other" (p. 131) [Emphasis in original].Self, in conversation, is usually identified with speaker and other is identified with hearer. In addition, politeness is shown by speaker to third parties "who may or may not be present in the speech situation" (p. 131). Leech (1983) proposes six maxims for his PP theory they are as follows:

I) TACT MAXIM [...] a) Minimize cost to other; b) Maximize benefit to other.

II) GENEROCITY MAXIM [...] a) Minimize benefit to self; b) Maximize cost to self.

III) APPROBATION MAXIM [...] a) Minimize dispraise of other; b) Maximize praise of other.

IV) MODESTY MAXIM [...] a) Minimize praise of self; b) Maximize dispraise of self.

V) AGREEMENT MAXIM [...] a) Minimize disagreement between self and other; b) Maximize agreement between self and other.

VI) SYMPATHY MAXIM [...] a) Minimize antipathy between self and other; b) Maximize sympathy between self and other(Leech 1983, p. 132) [Emphasis in original].

Along these lines Searle (1975) suggests the area of directives as the most useful to study in the field of indirect illouctionary acts "because ordinary conversational requirements of politeness normally make it awkward to issue flat imperative sentences (e.g., Leave the room) or explicit performatives (e.g., I order you to leave the room), and we therefore seek to find indirect means to our illocutionary ends (e.g., I wonder if you would mind leaving the room)" (Searle 1975, p. 64). Thus, politeness, for him, is "the most prominent motivation for indirectness in requests" (Searle 1975, p. 76).Moving on to IP, Leech (1983) maintains that "If you must cause offence, at least do so in a way which doesn't overtly conflict with the PP, but allows the listener to arrive at the offensive point of your remark indirectly, by way of implicature"(p. 82). The IP for Leach is a "substitute for impoliteness" and a "second-order principle" (p. 142). It allows "a speaker to be impolite while seeming to be polite; it does so by superficially breaking the CP, but ultimately upholding it" (p. 142).

\section{Methodology}

It is needless to say that accounting for the pragmatic properties of every single QIPV is by far beyond the scope of this study. Thus, a qualitative approach to the topic at hand is adopted. This being said, a number of Qur'anic verses are selected as illustrative data. In our analysis, we shall consider the data from the following perspectives: First, the context of each verse is attended to. Next, the QIPV used in that verse, its syntactic and semantic features are accounted for. Then, pragmatic principles, maxim flouted and implicature intended are highlighted. To do justice to this perspective, the two levels of analysis proposed by Grice (1975), i.e. what is said and what is implicated levels, will be considered. Scrutinizing the data at the first level would enable us to account for its propositional, linguistically encoded, semantic meaning (i.e. the locutionary act), whereas doing so at the second level would allow us to underscore its pragmatic properties and in turn to determine the intended communicative meaning (i.e. the illocutionary force). In addition, politeness principle and irony principle are referred to here and there when appropriate. The illustrative examples of the QIPVs are contextualized and analysed in an attempt to establish an implicutural interpretation for the phenomenon of QIPVs.

\section{Data and Discussion}

Being a book of guidance with a divine source, the Qur'an addresses all mankind throughout generations. Its divine message is not limited to those contemporaries of its revelation time who live in the Arabian Peninsula. Therefore, its discourse is characterized by employing different means to perform a variety of speech acts for fulfilling different purposes. A close look at the Qur'anic discourse reveals that both, to use Searle's terms, direct and indirect speech acts are employed. Accounting for all the Qur'anic speech acts performed falls out of the scope of this study. What is relevant to our topic is that QIPVs are employed in a range of Qur'anic structures to perform various speech acts. 
In what follows, we shall utilize the above-mentioned method to investigate the QIPVs that are employed to perform direct speech acts followed by those employed to perform indirect speech acts, i.e. conversational implicatures.

\subsection{Direct Speech Acts Performed by QIPVs}

Let us start this section by citing Searle's definition of the notion of direct speech acts: The simplest cases of meaning are those in which the speaker utters a sentence and means exactly and literally what he says. In such cases the speaker intends to produce a certain illocutionary effect in the hearer, and he intends to produce this effect by getting the hearer to recognize his intention to produce it, and he intends to get the hearer to recognize his intention in virtue of the hearer's knowledge of the rules that govern the utterance of the sentence (Searle 1975, p. 59).

This being said, the QIPVs are used in the Qur'an to perform a number of direct speech acts achieving a wide range of purposes. The direct speech acts performed along with their illustrative examples are shown in Table 1 below:

\begin{tabular}{|c|c|c|}
\hline Direct Speech Act & Illustrative Example & Translation \\
\hline Commanding & وأتوا البيوت (البقرة: هن أبو ابها ) & $\begin{array}{l}\text { "So enter your houses by their [main] doors" (Abdel } \\
\text { Haleem 2010, p. 30). }\end{array}$ \\
\hline Requesting & 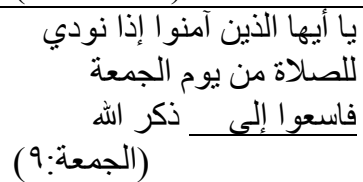 & $\begin{array}{l}\text { "Believers! When the call to prayer is made on the } \\
\text { day of congregation, hurry towards the reminder of } \\
\text { God" } \\
\text { (Abdel Haleem } 2010 \text {, p. } 555 \text { ). }\end{array}$ \\
\hline Pleading & قال رب اشرح لى صدري ب) & $\begin{array}{l}\text { "Moses said, 'Lord, lift up my heart" } \\
\text { (Abdel Haleem 2010, p. 314). }\end{array}$ \\
\hline Praying & و أكتب لنا في هذه الآنيا & $\begin{array}{l}\text { "Grant us good things in this world and in the life to } \\
\text { come. We turn to You" } \\
\text { (Abdel Haleem 2010, p. 171). }\end{array}$ \\
\hline Instructing & و اتخذو امن مقام إبر اهيم & $\begin{array}{l}\text { "Take the spot where Abraham stood as your place of } \\
\text { prayer" } \\
\text { (Abdel Haleem } 2010 \text {, p. } 20 \text { ). }\end{array}$ \\
\hline Supporting & 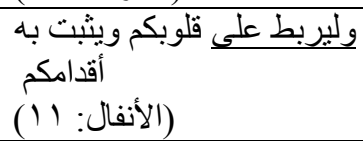 & $\begin{array}{l}\text { "... to make your hearts strong and your feet firm" } \\
\text { (Abdel Haleem } 2010, \text { p. 179). }\end{array}$ \\
\hline Forbidding & 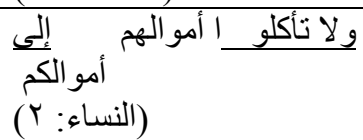 & $\begin{array}{l}\text { “... and do not consume their property along with } \\
\text { your own" } \\
\text { (Abdel Haleem } 2010 \text {, p. } 78 \text { ). }\end{array}$ \\
\hline Prai & 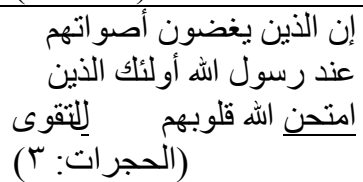 & $\begin{array}{l}\text { "It is those who lower their voices in the presence of } \\
\text { the God's Messenger whose hearts God has proved to } \\
\text { be aware" } \\
\text { (Abdel Haleem 2010, p. 516). }\end{array}$ \\
\hline Won & 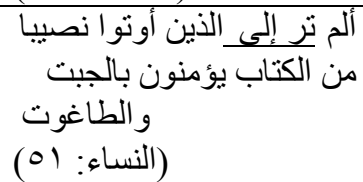 & $\begin{array}{l}\text { 'Do you not see how those given a share of the } \\
\text { Scripture, [evidently] now believe in idols and evil } \\
\text { powers?" } \\
\text { (Abdel Haleem 2010, p. 87). }\end{array}$ \\
\hline Threatening & ولو شاء اله ل لذهب بسمعهم & $\begin{array}{l}\text { "If God so willed, He could take away their hearing } \\
\text { and sight" } \\
\text { (Abdel Haleem 2010, p. 4). }\end{array}$ \\
\hline Regretting & 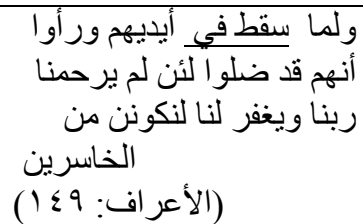 & $\begin{array}{l}\text { "When with much wringing of hands, they perceived } \\
\text { that they were doing wrong, they said, 'If our Lord } \\
\text { does not have mercy on us and forgive us, we shall be } \\
\text { the losers"” } \\
\text { (Abdel Haleem 2010, p. 169). }\end{array}$ \\
\hline
\end{tabular}




\begin{tabular}{|c|c|c|}
\hline Sympathizing & وما أريد أن أنشق على لك: & $\begin{array}{l}\text { "I do not intend to make things difficult for you" } \\
\text { (Abdel Haleem 2010, p. 389). }\end{array}$ \\
\hline Promise & ثم لآتينهم من بين أيديهم ومن خلفه & $\begin{array}{l}\text { "I do not intend to make things difficult for you" } \\
\text { (Abdel Haleem 2010, p. 389). }\end{array}$ \\
\hline Challenging & 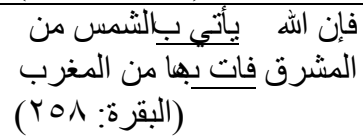 & $\begin{array}{l}\text { "God brings the sun from the east; so bring it from } \\
\text { the west" } \\
\text { (Abdel Haleem 2010, p. 44). }\end{array}$ \\
\hline
\end{tabular}

Table 1: Direct Speech acts performed by QIPVs

\subsection{Indirect Speech Acts Performed by QIPVs}

Indirect speech acts, as defined by Searle (1975), are "cases in which one illocutionary act is performed indirectly by way of performing another" (p. 60).The QIPVs are heavy-loaded structures with multi-layered significances. They are characterized by carrying both linguistically encoded significances and a number of implied significances, which are typically the significances intended by the addresser. The QIPVs are utilised in many places throughout the Qur'anic discourse to perform a wide range of conversational implicatures by flouting a number of Grice's maxims in order to achieve different communicative purposes.

\subsubsection{Implicatures of QIPVs}

Tracing all the conversational implicatures performed by QIPVs is by all means beyond the scope of this study due to time and space considerations. Five illustrative examples will suffice. The conversational implicatures performed by QIPVs are exemplified in the following Qur'anic verses:

\section{Example 1}

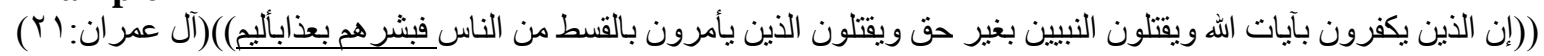

"Give news of agonizing torment to those who ignore God's revelations, who unjustifiably kill prophets, who kill those, who command that justice is done" (Abdel Haleem 2010, p. 53).This verse talks about disbelievers who keep committing crimes. It tells them about the serious consequences of their wrongdoings. The QIPV used in this verse is bashshara bi. This QIPV has also been employed in two other occurrences in the Qur'an, i.e., Q.84:24 and Q. 9:3.At the level of what is said, the propositional linguistically encoded meaning of the QIPV used in this verse (bashshara bi-) is 'to convey good news/to bring good tidings' (Badawi and Abdel Haleem 2008, p. 93). Yet, taking this propositional meaning would semantically contradict with the meaning of the object of the preposition $b i$ - and its adjective ('athäbinalīm) 'a painful torment'. This is because the verb bashshara is typically used in contexts of announcing good tidings not such bad tidings as a painful torment. At the level of what is implicated, this QIPV has been used metaphorically in this Qur'anic context to convey a particular communicative purpose. Pragmatically speaking, the superficial contradiction is deliberated from the part of the addresser to flout the maxim of RELATION by being irrelevant. This infringement of the RELATION maxim is done for the purpose of getting across a specific intended meaning, viz., IRONY. Such a usage is called by Arabic linguists al-Isti 'āra al-tahakkumyya 'ironic metaphor'. The implicature played here is that the addresser (God) wants through the addressee (the Prophet) to scorn and ridicule those who ignore his revelations, unjustifiably kill prophets, and kill those who command that justice is done. In so doing the addresser employs the QIPV bashshara bi- 'to convey good tidings' in a context whereby a painful torment is the 'good tidings'. Irony is one of the rhetorical tools frequently employed in the Qur'an to threat the unbelievers with the punishment of hell (Marogy 2010, p. 67). The QIPV bashshara bi- is an imperative one. The usage of the imperative form to perform irony is quite comment phenomenon in the Qur'an (Marogy 2010, p. 67).

\section{Example 2}

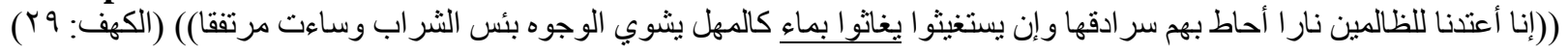

"We have prepared a Fire for the wrongdoers that will envelop them from all sides. If they call for relief, they will be relieved with water like molten metal, scalding their faces. What a terrible drink! What a painful resting place!" (Abdel Haleem 2010, p. 298).This verse describes the Fire that Allah prepares for the wrongdoers. It accounts for two aspects of that Fire. The first aspect is that it will surround them from everywhere. While the second aspect is that if the wrongdoers called for relief, they would be relieved with water like molten metal (cf. al-Rāzī 1981, 121:21; al-Zamakhsharī 1998, 583:3).The QIPV used in this verse is yughäthū bi-. 
The verbyughäthüis a passive present verb.Its basic meaning is'to be succoured, to be bailed out, or to be relieved' (Badawi and Abdel Haleem 2008, p. 678). The preposition bi-in this context is an instrumental. Its main function is to show the means by which the verb is performed (Dāwood, 2002, p.1: 170). At what is said level, the locutionary act/propositional meaning of the QIPV employed in this verse, i.e. yughäthūbi-, is 'to be succoured/bailed out/relieved with'. Yet, this propositional meaning evidently contradicts with the meaning of the object of the preposition $\mathrm{bi}$ - and its adjective $(m \bar{a}$ ' $\mathrm{kalmuhl})$ 'water like molten metal' for the succour and relief must be with something, which would help in satisfying the needs of those who call for relief not with something that would increase their torment. At what is implicated level, like the previous verse discussed in Example 1 above, the metaphorical employment of this QIPV in this Qur'anic context it not without a communicative purpose. The addresser intentionally violates the maxim of RELATION by being irrelevant in order to get across the intended implicatuer, viz., IRONY. The addresser wants to mockery those who are addressed in this Qur'anic discourse i.e. the wrongdoers by employing the QIPV yughäthübi- 'to be relieved with' in a context whereby the 'water like molten metal' is the substance with which they will be 'relieved'.

\section{Example 3}

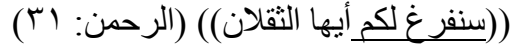

"We shall attend to you two huge armies [of jinn and mankind]" (Abdel Haleem 2010, p. 533). Allah in this verse is addressing both jinn and mankind telling them that he will take them to task. The QIPV used in this verse is faragha li-. The verb faragha literally means to become vacated; to take leisure; to complete an assignment, to become free of tasks, and to free oneself of all duties (Badawi and Abdel Haleem 2008, p.703). The preposition liin this context signifies habitual belonging (al-ikhtișāss)(Dāwood, 2002, p.1: 293).At what is said level, the locutionary act/propositional meaning of this verse is that Allah says to jinn and mankind that I will free myself exclusively to you/ attend to you/ take you to task (Badawi and Abdel Haleem 2008, p.703; Abdel Haleem 2010, p. 533). At what is implicated level, however, the addresser intentionally violates the maxim of MANNER by making his contribution ambiguous. The source of ambiguity in this verse is the usage of the verb faragha. It is a commonplace that Allah cannot be imagined to be too busy doing something that might prevent him from doing something else. This proposition would contradict with what he typically describes himself in many occasions throughout the Qur'an that he "has power over everything" (cf.Q. 2:20, 106, 109, 148, 259, 284 among others).The intended implicature here is that the addresser wants to threaten the addressees (cf. al-Raazi 1981, 111:29; al-Zamakhshari 1998, 13:6). This is shown by the usage of the future prefix $s a$ - and by the metaphorical employment of the QIPV faragha li- in that particular context.

\section{Example 4}

((و إذا مس الإنسان ضر دعا ربه منيبا إليه ثم إذا خوله نعمة منه نسي ما كان يدعو إليه من قبل وجعل لله أنداد ليضل عن سبيله قل تمتع بكفوك قليلا

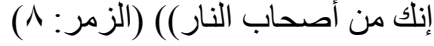

"When man suffers some affliction, he prays to his Lord and turns to Him, but once he has been granted a favour from God, he forgets the One he had been praying to and sets up rivals to God, to make others stray from His path. Say, 'Enjoy your ingratitude for a little while: you will be one of the inhabitants of the Fire" (Abdel Haleem 2010, p. 460).This verse talks about the contradictory and inconsistency ways the idols' worshipers adopting. They turn to Allah and pray to him only when they suffer some affliction in their life. Yet, when Allah saves them from that affliction, they forget his favour and go back to what they used to do, i.e. idols worshiping (cf. alRāzī1981, 295:2; al-Zamakhsharī 1998, 292:5). The QIPV used in this verse is tamatta ' bi-. The basic meaning of the verb tamatta' isto enjoy / to benefit (Badawi and Abdel Haleem 2008, p.866). The preposition bi- in this context denotesimmaterial affixing (al-ilșāqal-ma'nawî) (Dāwood, 2002, p.2: 180). At what is said level, the locutionary act/propositional meaning of the expression in which the QIPV is employed is that Allah is asking an idols' worshiper to enjoy his ingratitude for a little while 'tamatta' bi kufrika'. At what is implicated level, however, the addresser intentionally flouts the maxim of QUALITY by saying what he believes to be false. The source of such a falsity isthe metaphorical usage of the QIPV tamatta' $b i$ - in that context. The propositional meaning of tamatta' $b i$ - obviously contradicts with the meaning of the object of the preposition $b i$ - i.e., $k u f r$ (ingratitude/disbelief) since one normally enjoys good/positive deeds not such bad/negative ones as ingratitude and disbelief. The maxim of QUALITY is flouted here by the addresser for the purpose of getting across the intended implicature, that is, threatening the addressee and letting him down (cf. al-Zamakhsharī 1998, 292:5; alAsfahānī, n.d.,295:2). 


\section{Example 5}

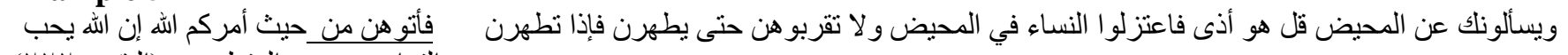

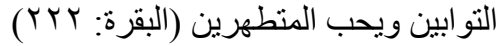

"They ask you [Prophet] about menstruation. Say 'Menstruation is a painful condition, so keep away from women during it. Do not approach them until they are cleansed; when they are cleansed, you may approach them as God has directed you. God loves those who turn to Him, and He loves those who keep themselves clean" (Abdel Haleem 2010, p. 36). This verse talks about husband-wife sexual relationship during menstruation time. It was revealed when one of the Prophet's companions, Abu al-Dahiāh, asked him: What shall we do with women during their menses? It is narrated that Arab in the pre-Islamic era would emulate Jews and Zoroastrians as to their treatment of women during their menses. They used to stop eating, drinking and living with women under one roof. Hence, this verse describes the menstruation as a painful condition and prohibits husbands from having sexual intercourse with their wives during it and gives them a permission to do so when the menses are over. (cf. al-Zamakhsharī 1998, 432:1; al-Rāzī1981, 67:6; Ayoub 1984, 225:1).The QIPV used in this verse is 'atā min. The verbi'tūhunnais an imperative form derived from the root 'atā, which basically means 'to come'. The preposition min here denotes start of destination(ibtid $\bar{a}^{\prime}$ al-ghāya) and signifies the place from which a husband should start the act of sexual intercourse (Dāwood, 2002, p. 1:91). At what is said level, the propositional meaning of the QIPV employed in this verse, i.e. i'tühunnamin, is 'come to them [women] from ...'. Yet, this propositional meaning stops short from delivering the intended meaning, which is a permission of having sexual intercourse with wives when the menses are over. At what is implicated level, the QIPV is employed here metaphorically to avoid direct reference to sex. The addresser purposefully flouts the maxim of QUANTITY by making his contribution less informative than is required in order to deliver the intended implicate, namely, EUPHEMISIM. It is to implicate that "the explicit mention of sexual intercourse is taboo and incongruent with the sanctity of the Quran (Farghal 1995, p. 372). The implicative is played in this verse to achieve politeness, which constitutes one of the key Qur'anic discourse characteristics (see for instance Q. 4: 23 and 43). The aim is to protect the modesty of the addressees and avoid any possible loss of face.

\section{Conclusion}

This article has cast some light on the pragmatic idiosyncrasies of the phenomenon of QIPVs. It provided a definition for the QIPVs, touched upon the key features of their syntactic and semantic peculiarities, and elaborated on their pragmatic properties. In an attempt to delineate a clear pragmatic depiction of QIPVs, the article has made use of the speech acts theory, cooperative principle theory, politeness principle theory, and irony principle theory. Utilising a qualitative data analysis, the study has shown that both direct and indirect speech acts are performed by utilizing the QIPVs. It has also demonstrated that the QIPVs are employed to flout a number of the maxims of conversation so as to bring forth a number of conversational implicatures. Finally, it is hoped that this study opens the door for further investigations of the QIPVs. It is also hoped that the study provides some practical insights for Arabists, constructivists,

\section{References}

Al-Așfahānī, A. (n.d.). Al-Mufradāt fì ghrīb al-Qur'ān. Maktabat Nizār Musțafā al-Bāz.

Abdel Haleem, M. A. S. (2010). The Qur'an: English Translation and Parallel Arabic Text. Oxford University Press. Oxford.

Aldahesh. A. Y. (2009). Translating Idiomatic English Phrasal Verbs into Arabic. UK. VDM Verlag Dr. Muller.

Aldahesh, A. Y. (2016a). Pinning Down the Phenomenon of Phrasal Verbs in Arabic. International Journal of language and Linguistics. 3 (1), pp. 12-24. ISSN 2374-8850 (Print), 2374-8869 (Online).

Aldahesh, A. Y. (2016b). Towards a Model for Analyzing and Assessing Translation of Qur'anic Idiomatic Phrasal Verbs. Arab World journal, Special Issue on Translation. (5), pp. 33-53. . ISSN 2229-9327.

Al-Rāzī, M. F. (1981). Mafātīḥ al-Ghayb. First Edition. Dār al-Fikr lil Tibā' ati wa al-Nashri wa al-Tawīz' . Beirut, Lebanon.

Al-Shamsān, A. I. (1986). Al-Fi 'il fì al-Qur 'an al-Karīm Ta 'adyatuhu wa Luzūmuhu. The Kuwait University.

Al-Shamsān, A. I. (1987). Qaḍ̄yā al-Ta 'ad̄̄ wa al-Luzūm fi al-Dars al-Nahwī. Matba' at al-Madan̄i. Juddah. Suadi Arabia.

Austin, J. L. (1975). How to do things with words. Oxford: Clearndon Press. 
Ayoub, Mahmoud. (1984). The Qur'an and Its Interpreters. State University of New York Press. Albany.

Al-Zamakhsharī, J. A. M. (1998). Al-Kashshāf 'an Haqā'iq ghawamid al-Tanzīl wa 'uyūn al-'aqūwīl fì wujūi alT'wìl. First Edition. Maktabat Al- ubaykān. Riyadh, Saudi Arabia.

Badawi, E. M. and Abdel Haleem, M. (2008) Arabic-English Dictionary of the Qur'anic Usage. Brill. Leiden. Boston.

Baker, M. (1992). In Other Words: A coursebook on translation. London and New York: Routledge.

Bell, R. (1991). Translation and Translating: Theory and Practice. London and New York: Longman.

Dāwood, M. M. (2002). Al-Qur'an al-Karīm Wa Tafā 'ul al-Ma 'ānī̄: Dirāsa Dilālya li Ta 'lluq Harf al-Jarr bi alFi 'il Wa 'Atharahu fì al-Ma 'nā fì al-Qur'an al-Karìm. Dār Gharīb. Cairo. Egypt.

Farghal, M. (1995). Euphemism in Arabic: A Gricean Interpretation.Anthropological Linguistics, 37(3), pp. 366378.

Fawcett, P. (2001). Linguistic approaches. In M. Baker (Ed.), Routledge Encyclopedia of Translation Studies. London and New York: Routledge.

Grice, H. P. (1975). Logic and Conversation. In Cole, P. and Margon, J. L. Syntax and Semantics, Vol. 3: Speech Acts, 41-58. Academic Press. London.

Hale, S. (1996). Pragmatic Considerations in Court Interpreting ARAL, 19 (1), 61-72.

Hale, S. B. (2004). The Discourse of Court Interpreting: Discourse practices of the law, the witness and the interpreter. Amsterdam/Philadelphia: John Benjamins Publishing Company.

Harnish, Robert M. (2010). Fragments and Speech Acts. In Iwona Witczak-Plisiecka. Pragmatic Perspectives on Language and Linguistics Volume I: Speech Actions in Theory and Applied Studies. Cambridge Scholars Publishing. UK.

Hatim, B. (2001). Discourse analysis and translation. In M. Baker (Ed.), Routledge Encyclopedia of Translation Studies. London and New York: Routledge.

Hatim, B. (2001). Pragmatics and translation. In M. Baker (Ed.), Routledge Encyclopedia of Translation Studies. London and New York: Routledge.

Hatim, B. (2001). Teaching and Researching Translation. London: Longman.

Hatim, B. (2001). Text linguistics and translation. In M. Baker (Ed.), Routledge Encyclopedia of Translation Studies. London and New York: Routledge.

Heliel, M. H. (1994). Verb-Particle Combinations in English and Arabic: Problems for Arab Lexicographers and Translators. In R. De Beaugrand, A. Shunnaq \& M. H. Heliel (Eds.), Language, Discourse and Translation in the West and Middle East. John Benjamins Publishing Company. Amsterdam and Philadelphia.

James, C. (1980). Contrastive Analysis. Longman. London.

Leech, G. (1983). Principles of Pragmatics. Longman. London.

Levinson, S. C. (1983). Pragmatics. Cambridge University Press. Cambridge.

Lentzner, K. R. (1977). Semantic and Syntactic Aspects of Arabic Prepositions. Unpublished doctoral dissertation, Georgetown University, Washington, D. C.

Marogy, A. E. (2010). Kitab Sibawayhi: Syntax and Pragmatics. Brill. Leiden. Boston.

Ryding, K. G. (2005). A Reference Grammar of Modern Standard Arabic. Cambridge University Press. UK.

Searle, J. R. (1969). Speech Acts: An Essay in The Philosophy of Language. Oxford: Alden \& Mowbray Ltd.

Searle, J. R. (1975). Indirect Speech Acts. Syntax and Semantics. Vol. 3, pp. 59-82

Wright, W. (1981). A Grammar of the Arabic Language (Third ed.). Beirut: Librairie Du Liban 